Article

\title{
Plato on the Responsible Use of Poetry and Fiction in The Republic and The Laws
}

Kristoffer A. Bolaños

\begin{abstract}
Today, it is not so common among teachers of philosophy and literature to attempt to understand what keeps young readers engrossed in fiction/poetry -is it the form, the beauty, the intertwining of character/circumstance (à la Sophocles), or just the spectacle of the scandal and outrage, even the mere popularity of the work? Should we also engage the moral implications of the work? We raise these questions as we heed the advice of Plato in Republic and the Laws about storytelling. Despite that he was almost too easily branded as an austere and too "legalistic" a philosopher, we might just be able to learn something from him that can be of use in teaching poetry, especially in dealing with the current generation of learners, many of which, if you may, have become mere passive consumerists.
\end{abstract}

Keywords: ethics, responsibility, culture, pedagogy

\section{Introduction}

7 he Greek philosopher Plato (428-348 B.C.) is one of the most appreciated but also one of the most misunderstood thinkers in Western history - we attribute the latter to the fact that it will take a lifetime to grasp the massive and voluminous collection of works and dialogues. One semester of reading the Republic alone can be truly intellectually gratifying but requires a whole lot of time and effort. If there is one sure thing that almost everyone can agree about, it is that Plato, without any suggestion of patronizing him, will continue to be recognized as a massively brilliant and inquisitive mind, one who is indispensable if one is to engage in any form of philosophical discourse. He will remain an unmistakable voice in today's social practices, politics, even education.

Like any major philosopher called to mind today, Plato can just as easily be branded, at times in the most haphazard and unsystematic fashion, as an overly austere, plain, severe, and at worst, a totalitarian thinker. These are stereotypes that never do justice to the beauty and harmony inherent in

(C) 2017 Kristoffer A. Bolaños

https://www.kritike.org/journal/issue 21/bolanos december2017.pdf

ISSN 1908-7330

(cc) $\mathrm{BY}-\mathrm{NC}-\mathrm{ND}$ 
his philosophical works. There are plenty to like and dislike about Plato. As the commentator Anthony Kenny was quick to tell, "The state that Socrates [through Plato] imagines in books 3 to 5 of the Republic has been both denounced as a piece of ruthless totalitarianism and admired as an early exercise of feminism." 1 As Plato suggested, the most elaborate education is reserved for the guardians only and not for the rest who have designated for themselves their place in the hierarchy; procreation and intercourse are to be regulated, guardians, although given resources free of charge, are not to own property, but women can also be auxiliaries - these are but some examples of social regulations to which a part of Plato's readership have expressed misgivings about. For this paper, efforts will be made to interrogate especially the portion in Book II of the Republic where Plato stressed the necessity of supervising and, at times, putting restraints on certain forms of story-telling, particularly to children - so much so that if we can avoid telling them about the gods, who often do not make the best role-models of themselves in terms of conduct, then we should do so. This part is, perhaps, what many enthusiasts of Greek tragic drama, mythology, and fiction would grumble about; many would argue that poetry should be totally exempt from all forms of restriction.

And this might serve as the main thrust of this paper project: We need to inquire if we, as educators, should critically interrogate, regulate, and correct (if they become too licentious) the way we teach poetry and narratives, because we see such as instrumental to the cultivation of characters and natures in the soul, for better or worse. But for argument's sake, we are compelled to raise some questions: is there such a thing as bad fiction, as Plato conceived? When, and under what circumstances, can a tragedy/fiction become dangerous?

We now seek Plato's voice in addressing these as we feel that Plato's demand for responsibility in checking what people read or listen to deserves a second look, not so much because we simply want to negate or censor them, but because they do have a profound influence on a person's imagination, disposition, and sense of valuation and worth. As Plato would have supposed, interrogating poetry (as opposed to terminating all poetry outright, which, we believe, was not Plato's idea!) has a lot to do with mastering one's soul, which happens to be a big part of the education of guardians.

${ }^{1}$ Anthony Kenny, Ancient Philosophy, vol. 1 of A New History of Western Philosophy (New York: Oxford University Press, 2004), 58.

(c) 2017 Kristoffer A. Bolaños

https://www.kritike.org/journal/issue 21/bolanos december2017.pdf

ISSN 1908-7330

(c) $)$ BY-NC-ND 


\section{Plato's Treatment of Poetry and Fiction: Some Appraisals}

Concluding the first book of the Republic by hinting that a man of justice is one that works out the excellence in his soul, Plato (through the character Socrates) lays down a starting point for further elaboration of what he deems to be a just city. In general understanding, the formation of a just city, for Plato, necessitates cultivation of excellence in every citizen if possible, but most especially, in the guardian, who is to rule. As such, the education of the guardian, who is characterized ideally to be "a lover of wisdom, highspirited, swift and strong by nature," ${ }^{2}$ must be regulated and planned carefully. Like a tender plant, a guardian must be nurtured right from childhood, and special emphasis must be devoted to how he was to be schooled. What was initially suggested was to train the child in the arts, which might constitute mousike, before immersing him into gymnastics and physical training. ${ }^{3}$ Of course, this necessitates for Plato a supervision of the child's literary understanding: "[We] first tell stories to children. These are, in general, untrue, though there is some truth in them." 4 Plato might be speaking here of myths and legends that we generally use as metaphors for everyday life, though they are fictional. Arts training in students, especially the young, now calls for a responsible supervision, and even storytellers will need to be checked. Here the character Adeimantus seems to agree with Socrates:

Shall we then carelessly allow children to hear any kind of stories composed by anybody, and to take into their souls beliefs which are for the most part contrary to those we think they should hold in maturity - We shall certainly not allow that. Then we must, first of all, control the storytellers. Whatever noble story they compose we shall select, but a bad one we must reject. Then we shall persuade nurses and mothers to tell their children those we have selected and by those stories to fashion their minds far more than they can shape their bodies by handling them. [However,] the majority of the stories they tell must be thrown out. ${ }^{5}$

\footnotetext{
2 Plato, Republic, trans. by G.M.A. Grube (Indianapolis: Hackett Publishing Co., 1974), 2.376c. Hereafter cited as Republic.

${ }^{3}$ Ibid., 2.376e.

${ }^{4}$ Ibid., 2.377a.

${ }^{5}$ Ibid., $2.377 \mathrm{~b}-\mathrm{c}$.
}

(c) 2017 Kristoffer A. Bolaños https://www.kritike.org/journal/issue 21/bolanos december2017.pdf ISSN 1908-7330 


\section{THE RESPONSIBLE USE OF POETRY AND FICTION}

The argument presented by Plato appears to be so: Regulation of narration and storytelling is necessary because we need to cultivate in men and women, even would-be guardians, the proper natures and characters as what should best fit them; any corrupt nature or character (say, for instance, of the envious and malevolent temperament of the gods of mythology) may just as easily be implanted in the minds of listeners as good and just naturesif we aim for a just society, care and supervision even in storytelling becomes indispensable. Plato appears to claim here, too, that whatever is instilled in a young mind stays with that mind even into advanced years of his life; a corruption introduced early in life, as with negative habits and custom, cannot be corrected easily. As we examine the text, we also do away with the misunderstanding that Plato totally rejects all kinds of poetry. On the contrary, he would allow poetry that is proper in the instilling of proper virtue. Plato was no hater of poetry. His position, though, is scorned at by other poetry enthusiasts as limiting and negating, because, for them, free exercise of poetry, like other forms of art, should operate well beyond imagined ethical boundaries. As such, Plato is labeled as austere and legalistic in approach. The point of Plato's argument, however, is reconsidered by other readers because guardianship demands, not only creative imagination, but also responsible, that is, ethical, rule and statecraft. This Platonic view was brought up once again by the Athenian in Laws, who viewed education as the activity of harmonizing the soul (especially of the young who are less diligent) which is likened to a physician's treatment of bodily ailments:

[J]ust as, when people suffer from bodily ailments and infirmities, those whose office it is try to administer to them nutriment that is wholesome in meats and drinks that are pleasant, but unwholesome nutriment in the opposite, so that they may form the right habit of approving the one kind and detesting the other. Similarly in dealing with the poet, the good legislator will persuade him-or compel him-with his fine and choice language to portray by his rhythms the gestures, and by his harmonies the tunes, of men who are temperate, courageous, and good in all respects, and thereby to compose poems aright. ${ }^{6}$

Contrary to what many critics hold, we are sure that the Plato of Laws was no despiser either of dramatic performance that calls for role-play and

${ }^{6}$ Plato, Laws, trans. by R.G. Bury (London: Harvard University Press, 1926), 2.660e. Hereafter cited as Laws.

(c) 2017 Kristoffer A. Bolaños

https://www.kritike.org/journal/issue 21/bolanos december2017.pdf

ISSN 1908-7330

(c) BY-NC-ND 
imitation. What he seems to be concerned about is the habituation of certain unbecoming conduct due partly to imitation. This is undeniable even in TV shows and movies today. Not only drunkenness, debauchery, wickedness, slavery to appetites, but also spiritual imbalance due to enslavement to passions, even "moral subservience," are habits that, as they become manifest in characters of a play, characters ranging from the chief to the peripheral, have the ability to create the impression of themselves as delightful and proper habits, especially to an unreflective audience. It is in this sense that fiction becomes detrimental to the soul. The television industry of our day, ${ }^{7}$ propelled by production and selling of extravagant sights and sounds, seems totally indifferent to the repercussions of demonstrating bad characters, and often glorifies them as worthy of emulation. What Plato seems to suggest, in both the Republic and the Laws, is that, although imitative poetry will remain as art, a reflection of oneself and one's action should accompany it. Plato's argument is implied in this brief exchange between Clinias and the Athenian Stranger, where the same philosopher puts his inquisitive mental processing at work:

ATH. Inasmuch as choric performances are representations of character, exhibited in actions and circumstances of every kind, in which the several performers enact their parts by habit and imitative art, whenever the choric performances are congenial to them in point of diction, tune or other features (whether from natural bent or from habit, or from both these causes combined), then these performers invariably delight in such performances and extol them as excellent; whereas those who find them repugnant to their nature, disposition or habits cannot possibly delight in them or praise them, but call them bad. And when men are right in their natural tastes but wrong in those acquired by habituation, or right in the latter but wrong in the former, then by their expressions of praise they convey the opposite of their real sentiments; for whereas they say of a performance that it is pleasant but bad, and feel ashamed to indulge in such bodily motions before men

7 Think, for instance, of the easy access of children to TV shows such as the Ultimate Fighting Championship that features gladiator-like fighters performing mixed martial arts (and thus, violence) on each other, merely for entertainment. Local TV is not exempt, because even children are exposed to noon time shows like Wowowee or similar programs, heavily infused with the notion of "easy money" and charged with sexuality by women dancing in skimpy wearand this is shown to everyone at midday.

(c) 2017 Kristoffer A. Bolaños https://www.kritike.org/journal/issue 21/bolanos december2017.pdf ISSN 1908-7330 
whose wisdom they respect, or to sing such songs (as though they seriously approved of them), they really take a delight in them in private.

CLIN. Very true.

ATH. Does the man who delights in bad postures and tunes suffer any damage thereby, or do those who take pleasure in the opposite gain there from any benefit?

CLIN. Probably.

ATH. Is it not probable or rather inevitable that the result here will be exactly the same as what takes place when a man who is living amongst the bad habits of wicked men, though he does not really abhor but rather accepts and delights in those habits, yet censures them casually, as though dimly aware of his own turpitude? In such a case it is, to be sure, inevitable that the man thus delighted becomes assimilated to those habits, good or bad, in which he delights, even though he is ashamed to praise them. Yet what blessing could we name, or what curse, greater than that of assimilation which befalls us so inevitably?

CLIN. There is none, I believe.

ATH. Now where laws are, or will be in the future, rightly laid down regarding musical education and recreation, do we imagine that poets will be granted such licence [sic] that they may teach whatever form of rhythm or tune or words they best like themselves to the children of law-abiding citizens and the young men in the choirs, no matter what the result may be in the way of virtue or depravity?

As one can probably realize from the foregoing analysis, Plato is not as plain and severe as most critics commonly imagine him to be. Such a thought can be reassuring to curious readers in a way that there should not be any cause for them to halt before getting past the first five pages of Plato.

8 Plato, Laws, 2.655e-656c.

(c) 2017 Kristoffer A. Bolaños

https://www.kritike.org/journal/issue 21/bolanos december2017.pdf

ISSN 1908-7330

(c) BY-NC-ND 
Furthermore, Plato is not bent on forever holding back the "secrets" of the mythological gods. He welcomes the divulging of such secrets by a master albeit to a more mature, substantially trained, level-headed, and emotionally stable apprentice, as Socrates suggested:

[Even] if the deeds of Cronos and what he suffered from his son were true [as it was told in Theogony, 453, 506], I do not think this should be told to foolish and young people; it should be passed over in silence. If there were some necessity to tell it, only a very few people should hear it, and in secret, after sacrificing not a pig but some great and scarce victim ... Nor should a young man hear it said that in committing the worst crimes he is not doing anything out of the way, or that, if he inflicts every kind of punishment upon an erring father, he is only doing the same as the first and greatest of the gods ... Nor indeed ... any tales of gods warring and plotting and fighting against each other ... if those who are to guard our city are to think it shameful to be easily driven to hate each other ... stories about Hera being chained by her son, or of Hephaestus being hurled from heaven by his father when he intended to help his mother from being beaten, nor the battle of the gods in Homer ... The young cannot distinguish what is allegorical from what is not, and the beliefs they acquire at that age are hard to expunge and usually remain unchanged. That may be the reason why it is most important that the first stories they hear should be well told and dispose them to virtue. ${ }^{9}$

This is perhaps good Socratic advice. Unfortunately, today, instead of watching over what they tell the masses, many storytellers would rather capitalize on controversy, and sensationalization (as with the mass media), exploiting petty quarrels and trivial competition in order to sell their work, and since the younger generation is not too inclined to reading substantial material (let alone philosophy), the market-driven media and television, the dramatic performances of peak time programming tend to take over.

There should be no harm in using Plato's lenses to identify contemporary problems in today's literature, arts, and cinema. One good example of an overly-sensationalized material, perhaps, without offending

${ }_{9}^{9}$ Plato, Republic, 2.378a-d.

(c) 2017 Kristoffer A. Bolaños https://www.kritike.org/journal/issue 21/bolanos december2017.pdf

ISSN 1908-7330 
the fans of Dan Brown, is his novel The Da Vinci Code, which sold for over 80 million copies since its first publication in 2003. In the same year, an interview was done by $\mathrm{CNN}$, and when Martin Savidge asked Brown how much of the story is fabricated and how much was true, the latter answered, "99 percent of it is true. All of the architecture, the art, the secret rituals, the history, all of that is true, the Gnostic gospels. All of that is - all that is fiction, of course, is that there's a Harvard symbologist named Robert Langdon, and all of his action is fictionalized. But the background is all true."10 It seems, then, that we can make the author wholly or partly liable (along with the media, of course) for the growing misconception among readers (especially the unreflective majority of them), that the contents of the book are actual historical facts, and not fictional. This interesting phenomenon occurs even if these readers picked up the book from the "fiction" shelf of the store. But the so-called "facts," as far as many level-headed historians are concerned, still remain lacking in evidence and are continuously being challenged; who would have imagined that so many from the younger generation today impulsively believe that Christ and Mary Magdalene were married and had children who, according to the movie that promoted the book, started the line of Mirovingian monarchs, and that, in line with gnostic teaching, the early Christians allegedly stole Christ's body and buried it somewhere? Perhaps, these notions are products of a playfully imaginative mind, but their veracity and authenticity call for further critical interrogation. However, a lot of overly-enthusiastic devotees to popular culture today would set aside debate and scientific investigation, and would rather engage in swallowing the spectacular, the provocative, and the scandalous - as if scandal and petty malice were the only things that could move their passions and excite their spirits! Compelled by necessity (and less on trying to prove scripture), we examine some opposition. Writers Carl Olson and Sandra Miesel, who are advancing ideas in their Ignatius Press website, were more than willing to dismiss many of Brown's assertions as historically inaccurate. ${ }^{11}$ For instance, contrary to Brown's claim that the divinity of Christ was established only by the Council of Nicaea in 325 A.D., a minority of Hebrew devotees as early as the first century (the apostles included) already saw Christ as possessing divinity; He even had a Hebrew name and was referred to as Mashiach (Messiah).12 The debate that transpired in the Council was about whether or

\footnotetext{
${ }^{10}$ Dan Brown and Martin Savidge, "An Interview with Dan Brown," in CNN (25 May 2003), <http://transcripts.cnn.com/TRANSCRIPTS/0305/25/sm.21.html>, 21 May 2017.

${ }^{11}$ Carl E. Olson and Sandra Miesel, "Facts vs. Fiction in The Da Vinci Code," in Ignatius Press (2006), < https://www.ignatius.com/promotions/davincihoax/thefacts.htm>, 21 May 2017.

12 The Hebrew believers of Yeshua whom they call Messiah were not actually addressed as "Christians," but rather they were better known as followers of the Way, which is the manner by which Shaul (Paul) introduced himself. "But this I confess to you, that according
}

(c) 2017 Kristoffer A. Bolaños

https://www.kritike.org/journal/issue 21/bolanos december2017.pdf

ISSN 1908-7330

(c) BY-NC-ND 
not the Son was co-equal with the Father, as claims to the "divinity" of the Son was already an existing culture. Another error found was concerning the explanation of Robert Langdon (the chief character in Brown's novel) about the origin of the tetragrammaton $\mathrm{YHWH}$; Langdon apparently stated that it came from the term Jehovah, an androgynous name that intertwines the masculine Jah and the pre-Hebraic name of Eve, Havah. For Olson and Miesel, nothing can be farther from the truth. And their position stands with teachers of Hebrew, the original language of scripture. One schooled in the Hebraic understanding (which apparently Brown was ignorant about) knows that Jehovah was derived from YHWH (יָוּה (:) which was the name first revealed to Moses and his people - an early occurrence in Deuteronomy 5:6 reads "I am Yahweh your Elohim, who brought you out of slavery in Egypt." Old Hebrew, characterized by picture-language, did not have vowels and the vowel points were only added later by the Masoretes for easier pronunciation and translation especially for non-Jewish Torah students; Accordingly, Yahweh and Jehovah must derive from the original tetragrammaton יהוָ;, but are considered references to the same God of Israel in scripture. And there is absolutely nothing androgynous about the name! Most readers would rather not go into detail but will embrace popular notions even if the propagators of such notions do not display historical competency.

Now the point here is not so much about becoming biblically apologetic as it is about being intellectually responsible, the lack of which must be a sure sign of cultural decline. Plato's cautions about mediocrity, about those who choose to remain "lovers of sights and sounds"13 without understanding the nature of what is true, become quite suitable in diagnosing contemporary culture. And this must be appropriately addressed.

Yet again, it cannot be overemphasized that Plato is willing to disseminate such classic narratives about mythological gods to a responsible and reflective mind-although perhaps he expects a manner of storytelling that teaches not just imitation but imitation with mental processing, with the prospect of surpassing degenerate culture, even the perverted culture of most mythological gods. Plato would have believed this kind of literary understanding to be attainable. Otherwise, he would not even have considered telling such narratives to any one at all, not even to philosophersin-the-making. Again, selective divulging of the details of myth to a trusted apprentice is up to the discretion of a skilled teacher, and situations like that do occur in academic circles.

By what means, then, do we recognize that an apprentice is worthy of hearing the secrets of the gods? Perhaps an important element of ethics,

to the Way, which they call a sect, I worship the God of our fathers, believing everything laid down by the Law and written in the Prophet." See Acts 24:14.

${ }^{13}$ Plato, Republic, 476c.

(c) 2017 Kristoffer A. Bolaños

https://www.kritike.org/journal/issue 21/bolanos december2017.pdf

ISSN 1908-7330

(cc) BY-NC-ND 
the recognition of oneself as a moral agent, as a moral individual capable of acting rightly or wrongly, and as a self who becomes accountable to his own actions (as opposed to acting because one is simply compelled to do so) is a quality that this apprentice must already possess. Accountability may be associated with the Greek term askēsis, which is, to borrow the characterization of the philosopher Michel Foucault, no other than the "exercise of oneself in the activity of thought."14 One good manifestation of askêsis perhaps is how one takes care of his speech; the importance of which cannot be underestimated. If one was told a secret, one can either treat it with confidentiality or spread it around, or worse, one can inflate and exaggerate to make the story of another person's life sellable, like a "good story" of another person's infirmities. Nowadays, even the media thrives on such character assassinations. Even if such information was true, it is not the business of a just man to kindle fire as to defame and slander others, rather, a just man would promote excellence in himself, and encourage others to do the same. In our day's consumer-driven environment of celebrity and fame, everything is consumed, even the private lives of people, leading to untold suffering, malice, degeneracy, and publicized men and women often resort to drug addiction and suicide. Bad culture, of course, can be avoided. Plato's advice: start with becoming responsible in disclosing and receiving information. And we must educate.

\section{Plato and the Potentials of Poetry in Transcending Culture}

Philosophy has long been associated with the enterprise of liberation, a kind of cultural critique as the social conditions of the time would requirethis has been the predisposition of philosophers ranging from Plato to Nietzsche. We can become physicians of culture indeed. But come to think of it, by what better vehicle can we carry out this preoccupation than by education in the letters, through storytelling, mythmaking, and poetry. The Plato of the Laws indeed held such a view. An educational and socially transformative function for culture, then, is assigned by him to poetry, epic, and tragic drama, without denying that these at the same time are pleasurable pursuits. The Athenian of the Laws, then, applauds poets and musicians who can entertain their spectators with rhythm, melody, or even with the anticipation of horror, fear and pity in classical tragedies. But more than that, the Athenian, if he was to award merrymakers, regards as better the most educated of poets:

\footnotetext{
${ }^{14}$ Michel Foucault, History of Sexuality Volume II: The Use of Pleasures, trans. by Robert Hurley (New York: Vintage Books, 1990), 9.

(c) 2017 Kristoffer A. Bolaños

https://www.kritike.org/journal/issue 21/bolanos december2017.pdf

ISSN 1908-7330

(c) BY-NC-ND
} 
I should regard that music which pleases the best men and the highly educated as about the best, and as quite the best if it pleases the one man who excels all others in virtue and education ... the true judge should not take his verdicts from the dictation of the audience, nor yield weakly to the uproar of the crowd or his own lack of education; nor again, when he knows the truth, should he give his verdict carelessly through cowardice and lack of spirit ... For, rightly speaking, the judge sits not as a pupil, but rather as a teacher of the spectators, being ready to oppose those who offer them pleasure in a way that is unseemly or wrong; and that is what the present law of Sicily and Italy actually does: by entrusting the decision to the spectators, who award the prize by show of hands, not only has it corrupted the poets (since they adapt their works to the poor standard of pleasure of the judges, which means that the spectators are the teachers of the poets), but it has corrupted also the pleasures of the audience ; for whereas they ought to be improving their standard of pleasure by listening to characters superior to their own, what they now do has just the opposite effect. ${ }^{15}$

Plato's proposal, then, is not to shun pleasure, and divorce it from poetry, for that would be the undoing of poetry itself. Instead, he calls for the pleasures, as generated in the crowd, the judges, the characters/role-players, to be thoroughly evaluated. Such pleasures may be gained from imitation (but not necessarily limited to that), usually drawn by the crowd from characters whom, by exhibiting authority, higher power, or moral ascendancy (as with gods and kings), they deem worthy of emulation-one can indeed imagine himself to be the hero Odysseus in order to take pleasure in Homer's epic. Pleasure can be gained from other means, of course. As Aristotle observed, there is pleasure, for instance, in endeavoring to follow the complex plot, as when tragedy keeps one preoccupied with the everchanging action: in the case of Oedipus Rex, there is movement from "finding the cure" towards "finding the slayer of Laius." Besides the action, an even more essential pleasure component of tragedy is the element of fear and pity, which arouses one's imagination. Even Aristotle favors fear and pity that comes not from the aid of primitive "spectacular display" but rather from the complex structure of the narrative itself, "Those who employ spectacular

${ }^{15}$ Plato, Laws, 2.659a-c.

(c) 2017 Kristoffer A. Bolaños

https://www.kritike.org/journal/issue 21/bolanos december2017.pdf

ISSN 1908-7330

(cc) BY-NC-ND 


\section{THE RESPONSIBLE USE OF POETRY AND FICTION}

means to create a sense not of the terrible but only the monstrous, are strangers to the purpose of tragedy...the pleasure which the poet should afford is that which comes from pity and fear through imitation."16 Such pleasure is achieved by imitation (portrayal) of roles within seemingly absurd but less "larger than life" circumstances, as when tragedy occurs between kindred and family relations, "if, for example, a brother kills, or intends to kill, a brother, a son his father, a mother her son, a son his mother, or any other deed of this kind-these are the situations looked for by the poet."17 Perhaps Aristotle, at least in part XIV of Poetics, was not too concerned yet with the moral implications of generated pleasures, and is rather focused on the quality of pleasures based on their point of origin; for him, it would be better if those pleasures would at least initiate a reflection about life and the fragility of human relations rather than from raw sights and sounds.

In Francis Fergusson's reading of Poetics, it was suggested that Aristotle was content with a summative theoria for Oedipus Rex dealing simply with how fleeting human life is, as Oedipus underwent the same course of existence like all other mortal men. ${ }^{18}$ True enough, the last lines of the Chorus goes: "... Behold this Oedipus, him who knew the famous riddles and was a man most masterful; not a citizen who did not look with envy on his lot-see him now and see the breakers of misfortune swallow him! Look upon that last day always. Count no mortal happy till he has passed the final limit of his life secure from pain."19 While this makes a lot of sense, a number of scholars, akin to a more Platonic view, might feel that there is a whole lot more to the story than just that.

And here is where a critique à la Plato may be of use. There is also à la tent message drawn from Sophocles, one that highly suggests an examination of culture: besides pitying Oedipus in his misfortune, readers should have been moved to protest the gods who excel more in bringing misfortune and death than comfort to the citizens of Thebes, or even against the people's lack of courage and initiative to take themselves out of their miserable conditions set by the gods. Such is the culture characterized by moral subservience. For Plato, such culture is a degenerate one, since a capitulation to it would mean that one's reason has been overcome by fear of the gods, or of the crowd, resulting to one's refusal to stand up against injustice. Let us not forget Plato's reminder about cowardice. Not every

${ }^{16}$ Aristotle, Poetics, trans. by H. Butcher (New York: Hill and Wang, 1961), XIV.4-7. Hereafter cited as Poetics.

${ }^{17}$ Ibid.

${ }_{18}^{18}$ Francis Fergusson, Introductory Essay to Aristotle, Poetics, 12-13.

${ }^{19}$ Sophocles, "Oedipus the King," trans. by David Greene in Greek Tragedies: Volume I, ed. by David Greene and Richmond Lattimore (Chicago: University of Chicago Press, 1960), 1530. Hereafter cited as Oedipus the King.

(c) 2017 Kristoffer A. Bolaños

https://www.kritike.org/journal/issue 21/bolanos december2017.pdf

ISSN 1908-7330

(cc) BY-NC-ND 
scholar is at home with the idea of blaming Oedipus for his own misfortune, as many traditional literary critics suppose. David Greene remarked, "It would be difficult to interpret Oedipus the King as a story of the punishment of pride," which is quite erroneous; he continues, "The deeds for which the hero would be 'punished' were pre-ordained before he was even conceived." 20 So how can we possibly interpret the story the other way?

Despite Plato's misgivings and reservations about the "majority" of poetic narratives, it is easy to imagine that he could have sympathized with a few exceptional characters of tragedy, had he come to know them. The titan Prometheus, in plays attributed to the poet Aeschylus, is one who can probably meet Plato's expectations, and exemplify a morally courageous character. In the infamous narrative retold by many as Prometheus Bound, Prometheus stole the fire (symbolic of knowledge) from Mt. Olympus and conferred it to man in order save man from destruction, granting the abilities necessary for human survival-not only kindling fire, but creating shelter, medicine, and the ability to use stone and metal, advanced understanding in science and mathematics, and so on. But in doing so, Prometheus suffered the wrath of Zeus, who had the titan chained to a rock in the Caucasian mountains, where his liver was to be eaten by a vulture day after day. ${ }^{21}$ Despite the tragic consequences born of courage and love (and not of pride), this may be viewed as an admirable display of spiritual beauty, characterized by sacrifice. More importantly, the liberating message of poetry is made even more explicit in Aeschylus' work, because the character Prometheus becomes symbolic of one who dares to transgress the boundaries set by the gods (Zeus was utilized as a tyrant figure), of one who dares to fight against injustice and moral servitude, instead of capitulating to the gods' passions, caprices, and whims by blind obedience.

It appears that Aeschylus remains true to what is generally conceived as the motivating theme behind the epics and tragic drama of Greek antiquity, which is the idea that man has the capability of making his own destiny through his own choices, be it for betterment or for ruin. But this theme is not exclusive to Aeschylus, for one might already find traces of it in the likes of Homer, or even hints of the same in other great dramatists such as Sophocles. True, Plato cannot hinder us from enjoying our poetry, but he constantly reminds us not to underestimate the power of myth in shaping culture and civilization.

\footnotetext{
${ }^{20}$ David Greene, Introduction to Oedipus the King in Greek Tragedies: Volume I, 108.

${ }^{21}$ See Donna Rosenberg and Sorelle Baker, Mythology and You: Classical Mythology and its Relevance to Today's World (Illinois: National Textbook Co., 1992), 104-7.
}

(c) 2017 Kristoffer A. Bolaños https://www.kritike.org/journal/issue 21/bolanos december2017.pdf ISSN 1908-7330 


\section{THE RESPONSIBLE USE OF POETRY AND FICTION}

\section{Conclusion}

That Plato remains relevant in contemporary situation is beyond doubt. We have learned that there is nothing wrong with igniting the passions with pleasurable verses, choruses, and rhyme. However, when it comes to the formation of culture, building the right character, and eventually establishing social harmony, we cannot go wrong by being selective, by becoming accustomed to habits that, despite being drawn from poetry and myth, are oriented to empowering, balancing, and nurturing the soul. The enjoyment of poetry by imitation should indeed be accompanied by responsible philosophical reflection.

We are, of course, aware that not everyone will be pleased by Plato's treatment of poetry. But if we were to put ourselves in the shoes of a man who was facing moral degeneracy in Athens in his day, many of us would probably understand why he was a little restrictive. To repeat what we have already established earlier, myth has, and will continue to have, an impact on the kind of lives we live, and the social realities we constitute for ourselves. And does our moral situation not resemble that of Plato's day? What is true perhaps is that there are "Zeus" figures that oversee the engines producing today's myths and legends, in literary production and filmmaking and other means, and unfortunately, they have succeeded in keeping us engrossed, enslaved to mere sights and sounds; we buy what is spectacular. In other words, literary production is now designed so that the passions will be excited more about the scandalous and trivial, and less about what is valuable-which is what Plato meant in speaking of the untrained and uncultured mind who, unwilling to test his pleasures, cannot tell the difference between the allegorical and the real. It would seem as if Plato would call on some souls to make a difference, not exactly to fancy themselves as Prometheus the titan, but to be philosophers in a more real sense-such a life will not be the most comfortable one, but such a life is what Plato would stylishly and poetically write about:

Of this small group, those who have become philosophers and have tasted how sweet and blessed a profession philosophy is, when they have fully realized also the madness of the majority ... that there is no ally with whom one might go to the help of justice and livethen like a man who has fallen among wild beasts, being unwilling to join in wrongdoing and not being strong

(c) 2017 Kristoffer A. Bolaños

https://www.kritike.org/journal/issue 21/bolanos december2017.pdf

ISSN 1908-7330

(cc) BY-NC-ND 
enough to oppose the general savagery alone ... he keeps quiet and minds his own business. ${ }^{22}$

That manner of life might bore a great majority, but would certainly bring stillness in the soul for the comfort of a select few who, away from the crowd's noisy pestilence,

[take] refuge under a small wall from a storm of dust or hail driven by the wind ... seeing other men filled with lawlessness, the philosopher is satisfied if he can somehow live his present life free from injustice and impious deeds, and depart from it with a beautiful hope, blameless and content. ${ }^{23}$

Life may be construed as an aesthetic of determining the best manner of existence before one enters his period of decline and eventual expiration. One must strive to keep one's soul undivided. This, too, is poetry.

Department of Philosophy and the Humanities Polytechnic University of the Philippines

\section{References}

Aristotle, Poetics, trans. by H. Butcher (New York: Hill and Wang, 1961).

Brown, Dan and Martin Savidge, "An Interview with Dan Brown," in CNN (25 May 2003), <http://transcripts.cnn.com/TRANSCRIPTS/0305/25 〈sm.21.html>, 21 May 2017.

Fergusson, Introductory Essay to Aristotle, Poetics, trans. by H. Butcher (New York: Hill and Wang, 1961).

Foucault, History of Sexuality Volume II: The Use of Pleasures, trans. by Robert Hurley (New York: Vintage Books, 1990).

Greene, Introduction to Oedipus the King in Greek Tragedies: Volume I, ed. by David Greene and Richmond Lattimore (Chicago: University of Chicago Press, 1960).

Kenny, Anthony, Ancient Philosophy, vol. 1 of A New History of Western Philosophy (New York: Oxford University Press, 2004).

Olson, Carl E. and Sandra Miesel, "Facts vs. Fiction in The Da Vinci Code," in Ignatius Press (2006), <https://www.ignatius.com/promotions /davincihoax/thefacts.htm>, 21 May 2017.

22 Plato, Republic, 6.496c-d.

${ }^{23}$ Ibid., 496e.

(c) 2017 Kristoffer A. Bolaños https://www.kritike.org/journal/issue 21/bolanos december2017.pdf ISSN 1908-7330 


\section{THE RESPONSIBLE USE OF POETRY AND FICTION}

Plato, Laws, trans. by R.G. Bury (London: Harvard University Press, 1926). Republic, trans. by G.M.A. Grube (Indianapolis: Hackett Publishing Co., 1974).

Rosenberg, Donna and Sorelle Baker, Mythology and You: Classical Mythology and its Relevance to Today's World (Illinois: National Textbook Co., 1992).

Sophocles, "Oedipus the King," trans. by David Greene in Greek Tragedies: Volume I, ed. by David Greene and Richmond Lattimore (Chicago: University of Chicago Press, 1960). 